\title{
Increased plasma levels of glucose-dependent insulinotropic polypeptide are associated with decreased postprandial energy expenditure after modern Japanese meals
}

\author{
Noriko Osaki $^{1} \cdot$ Chika Suzukamo $^{1} \cdot$ Kouji Onizawa $^{1} \cdot$ Tadashi Hase $^{1} \cdot$ \\ Akira Shimotoyodome ${ }^{1}$
}

Received: 25 December 2014 / Accepted: 15 April 2016 / Published online: 25 April 2016

(C) The Author(s) 2016. This article is published with open access at Springerlink.com

\begin{abstract}
Purpose The nutritional changes that have accompanied the modernization of Japanese dietary patterns have led to significant increases in the number of people who are overweight or obese. This study aimed to clarify the effects of these nutritional changes on postprandial energy expenditure and the release of metabolism-regulating hormones.

Methods The total daily energy content $(20 \%$ breakfast, $40 \%$ lunch, and $40 \%$ dinner) and macronutrient composition (carbohydrate/fat/protein) was $8807.3 \mathrm{~kJ}$ and 364.3:30.1:66.4 (g) for the traditional test diet and 9217.6 kJ and 331.7:66.1:76.9 (g) for the modern test diet. In experiment 1, nine healthy Japanese men participated in a crossover study during which they ingested a test diet comprising three meals; postprandial blood parameters were measured after each meal. In experiment 2 , another ten men participated in a crossover study during which they ingested 2 meals, after which metabolic responses and blood variables were evaluated.

Results The modern diet induced greater blood levels of glucose-dependent insulinotropic polypeptide (GIP) and ghrelin than did the traditional diet. The expected increase in postprandial energy expenditure ( $\triangle \mathrm{REE})$ tended to be dampened after the modern compared with the traditional diet. GIP was inversely correlated with $\triangle \mathrm{REE}$ after lunch, and ghrelin was positively associated with $\triangle$ REE.

Conclusion Both GIP and ghrelin are robust indicators of postprandial energy expenditure. The nutritional changes accompanying the modernization of Japanese dietary
\end{abstract}

Noriko Osaki

osaki.noriko@kao.co.jp

1 Biological Science Laboratories, Kao Corporation, 2606 Akabane, Ichikai-machi, Haga-Gun, Tochigi 321-3497, Japan patterns may increase the levels of the anabolic intestinal hormone GIP, which is associated with $\triangle \mathrm{REE}$, in the Japanese population. The contribution of an increased ghrelin concentration to the decreased $\triangle \mathrm{REE}$ after the modern diet warrants further investigation.

Keywords Gastrointestinal hormones - Ghrelin . Glucose-dependent insulinotropic polypeptide $\cdot$ Japanese meal $\cdot$ Postprandial energy expenditure

$\begin{array}{ll}\text { Abbreviations } \\ \text { CCK } & \text { Cholecystokinin } \\ \text { GIP } & \text { Glucose-dependent insulinotropic polypeptide } \\ \text { GLP-1 } & \text { Glucagon-like peptide-1 } \\ \text { iAUC } & \text { Incremental area under the curve } \\ \text { NEFA } & \text { Non-esterified fatty acid } \\ \text { PP } & \text { Pancreatic polypeptide } \\ \text { PYY } & \text { Peptide YY } \\ \text { REE } & \text { Resting energy expenditure } \\ \text { TG } & \text { Triglycerides } \\ \mathrm{VCO}_{2} & \text { Carbon dioxide consumption } \\ \mathrm{VO}_{2} & \text { Oxygen consumption }\end{array}$

\section{Introduction}

Obesity increases the risk of several health conditions, including hypertension, hyperlipidemia, and type 2 diabetes [1], and significantly increases healthcare costs. The World Health Organization (WHO) reported that more than one billion adults were overweight worldwide in 2009, with more than 300 million of them being clinically obese. According to WHO criteria, Japan had the lowest rate of obesity (approximately $3.9 \%$ ) among the OECD member countries in 2009 [2]. The onset and progression of obesity 
are closely related to lifestyle habits involving dietary patterns, physical activity, rest, tobacco use, and alcohol consumption.

Traditional Japanese dietary patterns are characterized by the high consumption of soybean products, fish, root crops, seaweeds, mushrooms, vegetables, fruits, and green tea [3]. Many epidemiologic studies have shown that the consumption of these food items or the adherence to a traditional Japanese dietary pattern in itself is inversely associated with lifestyle-related illnesses, such as cardiovascular disease, cancer, high blood pressure, high serum lipid levels, and diabetes [4-7]. In addition, the traditional Japanese diet has drawn considerable attention since the 1960s because of its association with an extremely low rate of coronary heart disease [8].

However, the National Health and Nutrition Survey has revealed that dietary patterns in Japan are becoming increasingly westernized. The consumption of rice (a conventional staple food for Japanese), soy, and fish has been decreasing since the 1960s, such that meat and products containing wheat flour are now preferred by the Japanese population. Although the average total energy intake has not changed significantly, the consumption of dietary fat, especially animal fat, by the Japanese population has increased [3, 9]. Along with the observed changes in dietary nutrient composition, the number of overweight and obese Japanese is increasing, especially among men in their 30s to 60s. The 2008 report of the National Health and Nutrition Survey stated that $28.6 \%$ of men and $20.6 \%$ of women in Japan were considered to be obese or overweight [10]. Whereas an adverse dietary nutrient composition such as high fat content is known to increase the risk of obesity, how changes in nutrient composition affect energy balance in humans has yet to be elucidated.

Several mechanisms may explain the effect of nutrient composition on energy balance. One potential mechanism may involve the release of gastrointestinal hormones by specialized enteroendocrine cells after the ingestion of nutrients. Recent studies have shown that gastrointestinal hormones play an important role in regulating energy balance. For example, peptide YY (PYY) [11, 12], ghrelin [13-16], glucose-dependent insulinotropic polypeptide (GIP) [17-27], and glucagon-like peptide 1 (GLP-1) [17, 21, 25-27] are known to regulate energy metabolism and appetite. Accordingly, these hormones have been the focus of increased interest due to their therapeutic potential for the treatment of obesity. In addition, several studies have proposed that dietary nutrient composition may influence the postprandial energy balance by regulating gastrointestinal hormones.

Therefore, the principal aim of the current study was to clarify how the nutritional changes associated with the modernization of the Japanese diet affect postprandial energy metabolism and gastrointestinal hormone responses. To this end, we compared postprandial energy expenditure and the postprandial blood levels of various metabolismregulating hormones in healthy Japanese men after their consumption of traditional or modern Japanese meals.

\section{Materials and methods}

\section{Subjects}

Healthy Japanese adult men (age, 20-59 years) were recruited for this study. Subjects provided written informed consent prior to the study. Subjects had no history of diabetes mellitus or food allergies and showed no abnormalities on physical examination.

This study was conducted according to the guidelines of the Declaration of Helsinki, and all procedures involving human subjects were approved by the Ethics Committee of Kao Corporation.

\section{Experimental design}

All subjects abstained from alcohol and exercise for 2 days before beginning the study. The evening before each test day, subjects consumed the same dinner (fat content, $25.4 \mathrm{~g}$; total energy content, $3740 \mathrm{~kJ}$ [894 kcal]) before 21:00 h; participants abstained from additional food intake for at least $12 \mathrm{~h}$ and from ingesting water for at least $3 \mathrm{~h}$ before testing. Subjects arrived at the test site between 08:00 and 08:30 $\mathrm{h}$ of the test day.

\section{Test meals}

Test meals were prepared to reflect the average nutrient composition of the Japanese diet according to the National Health and Nutrition Survey in Japan of 1960 (traditional test diet) and 2008 (modern test diet). For the traditional test diet, breakfast consisted of polished rice, miso soup, natto, and Japanese pickles. Lunch comprised polished rice, miso soup, mackerel, boiled vegetables, bean curd (tofu), an orange, and Japanese pickles. Dinner consisted of polished rice, miso soup, sardines, boiled vegetables (squash and broccoli), and boiled kidney beans with dressing. The total energy content of the 3-meal traditional test diet was $8807.3 \mathrm{~kJ}$ ( $20 \%$ breakfast, $40 \%$ lunch, and $40 \%$ dinner), and the macronutrient composition (carbohydrate/fat/protein) was 364.3:30.1:66.4 g (energy \%, 73.1:13.6:13.3). The total energy content of the 2-meal traditional test diet was $5333.2 \mathrm{~kJ}$ ( $31 \%$ breakfast and $69 \%$ lunch), and the macronutrient composition (carbohydrate/fat/protein) was 216.8:19.7:39.2 g (energy \%, 72.2:14.8:13.1). 
For the modern Japanese test diet, breakfast consisted of toast, ham salad, apple juice, and fruit yogurt. Lunch comprised pork curry and rice, tuna salad, yogurt, and pieces of pineapple. Dinner consisted of polished rice, miso soup, beef and pork patties, spinach, squash with cheese, and an orange. The total energy content of the 3-meal modern Japanese test diet was $9217.6 \mathrm{~kJ}$ (20\% breakfast, $40 \%$ lunch, and $40 \%$ dinner), and its macronutrient composition (carbohydrate/fat/protein) was 331.7:66.1:76.9 g (energy \%, 59.5:26.7:13.8). The total energy content of the 2-meal modern test diet was $5911.2 \mathrm{~kJ}$ (34\% breakfast and $66 \%$ lunch), and the macronutrient composition (carbohydrate/fat/protein) was 195.3:41.1:48.3 g (energy \%, 58.1:27.5:14.4). The energy content and macronutrient composition of the test meals were calculated according to the Standard Tables of Food Composition in Japan 2010.

\section{Experiment 1: Evaluation of blood parameters after consumption of traditional compared with modern Japanese test meals}

Nine male volunteers (age, $32.6 \pm 2.3$ year; body weight, $72.8 \pm 4.6 \mathrm{~kg}$; body mass index, $23.7 \pm 1.4 \mathrm{~kg} / \mathrm{m}^{2}$ ) participated in the study.

At $08: 15 \mathrm{~h}$, before the ingestion of the first test meal, blood samples (approximately $200 \mu \mathrm{L}$ ) for analysis of fasting blood parameters were collected into heparinized capillary tubes (75 mm length; Drummond Scientific, Broomall, PA, USA) by pricking a finger with a single-use sterile capillary blood sampling device (BD Genie Lancet, Becton-Dickinson, Tokyo, Japan). Blood samples were transferred into capillary blood collection tubes (CapiJect with EDTA-2Na, Terumo Medical, Tokyo, Japan) containing dipeptidyl peptidase IV inhibitor (Millipore, Tokyo, Japan) and maintained on ice until plasma preparation. All subsequent blood samples were obtained in the same way and volume, thus yielding at least $90 \mu \mathrm{L}$ plasma per sample, which was the minimum needed to measure all blood variables in duplicate by using the multiplex hormone assay. Breakfast was served at 08:30 h, lunch at 12:30 h, and dinner at 18:30 h. Subjects ingested each test meal within 10-15 min. The test diets were given in a random order (traditional or modern), with an interval of at least 7 days between diets. Over the postprandial period, blood samples were taken at 09:00, 09:30, and 10:30 h (after breakfast); 12:30, 13:00, 13:30, 14:30, and 16:30 h (at or after lunch); and 18:30, 19:00, 19:30, 20:30, and 21:30 h (at or after dinner). After centrifugation, plasma was stored at $-80{ }^{\circ} \mathrm{C}$ until analysis.
Experiment 2: Assessment of energy metabolism after ingestion of traditional compared with modern Japanese test meals

Ten male volunteers (age $36.8 \pm 2.4$ year; body weight $75.8 \pm 4.4 \mathrm{~kg}$; body mass index $24.9 \pm 2.1 \mathrm{~kg} / \mathrm{m}^{2}$ ) participated in the study.

At 08:30 h (before breakfast), baseline blood samples (approximately $3 \mathrm{~mL}$ ) were collected from a central vein into tubes containing proprietary stabilizers (P700 tubes, Becton-Dickinson). The blood samples were supplemented with a protease inhibitor (P2714-BTL, Sigma, Tokyo, Japan) and serine protease inhibitor (Pefabloc SC, Roche Diagnostics, Tokyo, Japan) and were maintained at room temperature until plasma preparation. Breakfast was served at 09:00 $\mathrm{h}$ and lunch at 13:15 h. Subjects ingested each test meal (prepared as described for experiment 1) within 10-15 min. The test diets were given randomly and unblinded (traditional or modern), with an interval of at least 7 days between diets. During the postprandial period, blood samples were collected at 10:00 h (after breakfast) and at 13:00, 14:15, 17:15, and 19:15 h (after lunch). After centrifugation, plasma was stored at $-80{ }^{\circ} \mathrm{C}$ until analysis.

During the experimental period, indirect calorimetry was performed 8 times: before breakfast ( -15 to $0 \mathrm{~min})$; at 30-45, 60-75, and 240-255 min after breakfast; and at 30-45, 60-75, 240-255, and 360-375 min after lunch. Briefly, respiratory metabolic performance in the sedentary condition was measured by using an open-circuit ventilated-hood system (VO2000, Medical Graphics, St. Paul, $\mathrm{MN}$, USA). Gas exchange rates were recorded on every third expiration. During each 15-min session, baseline data were collected during the first $5 \mathrm{~min}$ (equilibration period); data collected during the remaining $10 \mathrm{~min}$ were averaged to calculate resting energy expenditure (REE, $\mathrm{kJ} /$ day) and the respiratory exchange ratio (RER). The measured values of oxygen consumption $\left(\mathrm{VO}_{2}\right)$ and carbon dioxide production $\left(\mathrm{VCO}_{2}\right)$ were converted to REE according to the Weir equation [28] by using a specialized software program (m-Graph, S\&ME, Tokyo, Japan). The software also was used to estimate the respiratory exchange ratio (that is, $\mathrm{VCO}_{2} / \mathrm{VO}_{2}$ ) and substrate utilization from the gasexchange data.

The physical activity of the subjects during the experimental period was monitored by using an Actimarker (model EW48001, Panasonic Electric Works, Osaka, Japan) attached to the right hip. The device had a built-in triaxial accelerometer, which measured the 3 axes of acceleration (xi, up and down; yi, left and right; zi, forward and backward). 


\section{Blood analysis}

Blood glucose was determined by using a blood glucose self-monitoring device (Accu-Check Comfort, Roche Diagnostics) immediately after blood collection. Plasma levels of TG and non-esterified fatty acids (NEFA) were determined by using spectrophotometric methods (triglyceride E-test and NEFA-C test assay kits, Wako Pure Chemical Industries, Osaka, Japan). Plasma insulin, active ghrelin, PYY, and pancreatic peptide (PP) were measured on an automated system (Luminex 100 Total System, Luminex, Austin, Texas, USA) using Bio-Plex 200 reagents (BioRad, Hercules, CA, USA) and the Milliplex Map Kit Human Gut Hormone Panel (Millipore). Total GIP and active GLP-1 were measured by using an ELISA Kit (Linco Research, St. Charles, MO, USA). Plasma cholecystokinin (CCK) was determined by using an enzyme immunoassay kit (Cholecystokinin Octapeptide; 26-33; non-sulfated; human, rat, mouse; Phoenix Pharmaceuticals, Burlingame, CA, USA).

\section{Statistical analysis}

Numerical data are expressed as mean \pm SD. All postprandial blood analyte concentrations were compared with baseline data by using repeated-measures ANOVA in Graph Pad Prism 6 (MDF, Tokyo, Japan) to evaluate the effects of time and each type of meal when the data were normally distributed. Post-breakfast changes were calculated by using the values at $0 \mathrm{~h}$ (immediately before breakfast consumption) as baseline, post-lunch changes were determined relative to values at $4 \mathrm{~h}$ (immediately before lunch consumption), and post-dinner changes used the values at $10 \mathrm{~h}$ (immediately before dinner consumption) as baseline. In addition, incremental areas under the curve (iAUCs) were calculated for blood parameters and $\triangle \mathrm{REE}$ by using the trapezoidal method [29], whether cumulatively or separately for each the post-breakfast, post-lunch, and the postdinner. Wilcoxon signed-rank tests and Spearman's rank correlation coefficients were used when comparing paired samples whose data were not normally distributed (EXCEL Multiple Classification Analysis version 5.0, Esumi, Tokyo, Japan). Differences were considered significant when the error probability was $<0.05$.

\section{Results}

\section{Differences in postprandial blood responses} between traditional and modern Japanese test meals

Baseline data from the nine Japanese adult male participants did not differ between the test diets (Fig. 1). Within each diet, all test parameters except PYY (Fig. 1g) demonstrated significant $(P<0.001)$ differences between baseline and postprandial concentrations.

In particular, total GIP concentrations throughout the study differed significantly $(P<0.05)$ between the traditional and modern Japanese test diets (Fig. 1d). Postprandial TG (Fig. 1c) and total GIP (Fig. 1d) levels demonstrated significant $(P<0.001)$ interaction between time and diet. Plasma total GIP concentrations increased after each meal and peaked within $2 \mathrm{~h}$ after breakfast and $1 \mathrm{~h}$ after lunch and dinner and did not decline to basal (i.e., pre-meal) levels. The iAUCs of total GIP after each meal (breakfast, lunch, and dinner) were higher after the modern diet than after the traditional diet, whereas those of blood TG did not differ significantly between the test diets (Table 1). The postprandial total GIP responses (iAUCs) after the breakfast, lunch, and dinner of the modern Japanese test diet were 153,145 , and $241 \%$ of those after the traditional Japanese meals (Table 1).

Unlike TG and GIP concentrations, blood levels of glucose (Fig. 1a), insulin (Fig. 1b), NEFA (Fig. 1e), active ghrelin (Fig. 1f), PYY (Fig. 1g), and PP (Fig. 1h) throughout the study did not differ significantly between the test diets. Furthermore, the iAUCs for blood glucose, TG, and insulin after each meal (breakfast, lunch, and dinner) did not differ significantly between the test diets (Table 1), nor did those for NEFA, active ghrelin, PYY, and PP (data not shown).

\section{Differences in postprandial energy expenditure between traditional and modern Japanese diets}

All participants completed all trials $(n=10)$; however, the measurement was not stable for the bad condition of VO2000 in one participant, and data for indirect calorimetry evaluation and blood responses are presented from 9 participants. The initial energy metabolism and blood variables were similar between the test diets.

The physical activity of subjects did not differ between the test diets (data not shown).

Compared with that of the traditional diet, the postprandial increase in REE ( $\triangle$ REE) of the modern diet tended to be lower soon after the meal ingestion but higher during the later hours, but the difference between the diets at each postprandial time point was not significant $(P>0.05)$ (Fig. 2). The incremental area under the curve (iAUC) of $\triangle \mathrm{REE}$ at $4 \mathrm{~h}$ after breakfast did not differ significantly between the test diets. In contrast, the iAUC of $\triangle \mathrm{REE}$ at $6 \mathrm{~h}$ after lunch was significantly $(P<0.05)$ lower after the modern Japanese test meals than after the traditional ones when the values immediately before lunch (at $4 \mathrm{~h}$ ) were used as the baseline levels (Table 2). However, when the values immediately before breakfast (at $0 \mathrm{~h}$ ) were used as 
Fig. 1 Blood glucose (a), insulin (b), triglycerides (TG; c), total glucose-dependent insulinotropic polypeptide (GIP; d), non-esterified fatty acids (NEFA; e), active ghrelin (f), peptide YY (PYY; $\mathbf{g}$ ), and pancreatic peptide (PP; $\mathbf{h})$ concentrations until $13 \mathrm{~h}$ after the consumption of the traditional Japanese test diet (open circles) or modern Japanese test diet (closed circles) in overnight-fasted healthy Japanese men. Data are expressed as mean $\pm \mathrm{SD}(n=9$ in each group) and were analyzed by means of 2-way repeated-measures ANOVA

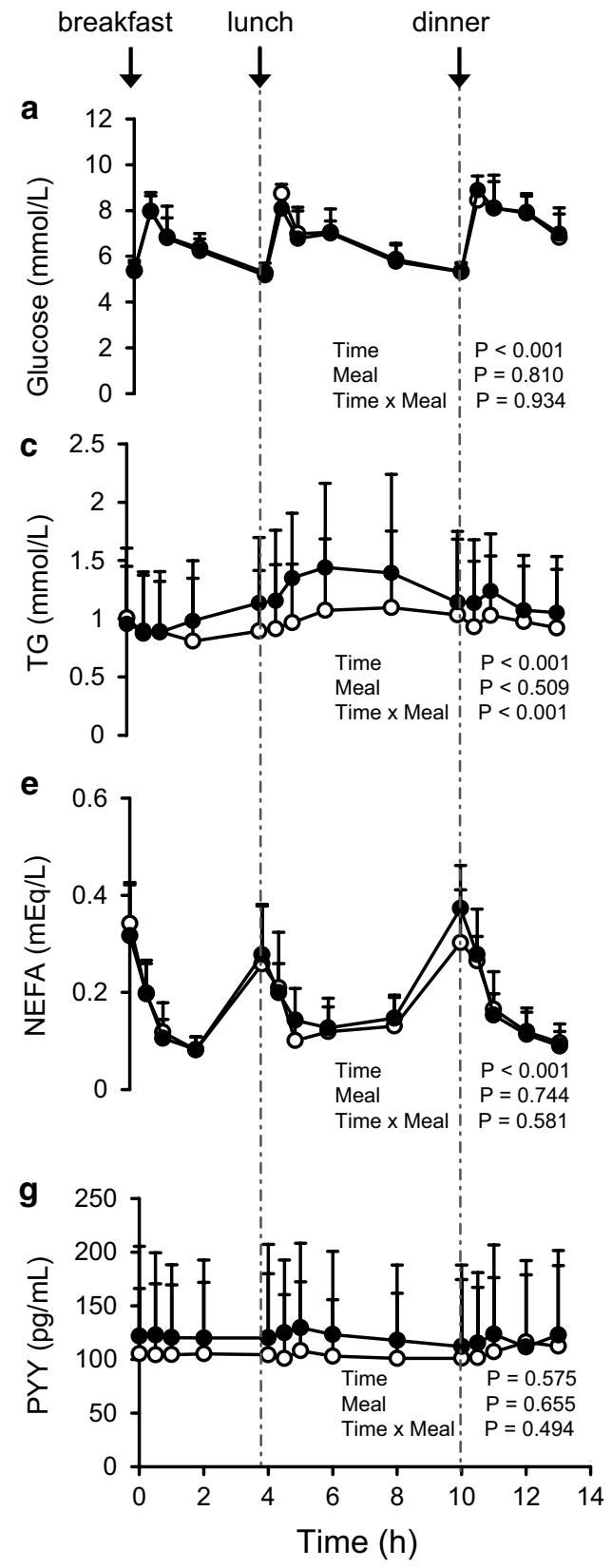

the baseline levels, the iAUC of $\triangle \mathrm{REE}$ after lunch did not differ between the test diets (Table 2).

The respiratory exchange ratio was slightly lower after ingestion of the modern Japanese diet than after ingestion of the traditional diet. Neither fat nor carbohydrate utilization during the experimental period $(10 \mathrm{~h})$ differed significantly between the test diets (data not shown).

As seen for the participants who ingested three meals, postprandial TG $(P<0.001)$ and total GIP $(P<0.01)$ differed significantly between diets among the second group of participants, who ingested two meals each (Fig. 3). Postprandial blood TG was significantly higher at $4 \mathrm{~h}$ after breakfast $(P<0.05)$ and at $1 \mathrm{~h}$ after lunch $(P<0.01)$ for the modern compared with the traditional Japanese diet. Postprandial blood GIP was significantly higher at $4 \mathrm{~h}$ $(P<0.01)$ and at $6 \mathrm{~h}(P<0.05)$ after lunch for the modern compared with the traditional Japanese diet. The iAUCs for total GIP and active ghrelin after each meal (breakfast and lunch) (Table 3) - but not those for blood glucose, TG, NEFA, insulin, active GLP-1, and CCK concentrations (data not shown) - differed significantly $(P<0.05)$ between the test diets.

In addition to the effects on postprandial TG and GIP levels, the postprandial active ghrelin response showed a 
Table 1 Postprandial incremental areas under the curve (iAUCs) of blood glucose, TG, insulin, and total GIP

\begin{tabular}{|c|c|c|c|}
\hline & & Traditional & Modern \\
\hline \multicolumn{4}{|l|}{ Glucose } \\
\hline $\begin{array}{r}\text { iAUC (after } \\
\text { breakfast) }\end{array}$ & $(\mathrm{mmol} 4 \mathrm{~h} / \mathrm{L})$ & $3.90(1.30)$ & $3.73(1.58)$ \\
\hline $\begin{array}{l}\text { iAUC (after } \\
\text { lunch) }\end{array}$ & $(\mathrm{mmol} 6 \mathrm{~h} / \mathrm{L})$ & $5.47(2.36)$ & $5.48(2.46)$ \\
\hline $\begin{array}{c}\text { iAUC (after } \\
\text { dinner) }\end{array}$ & $(\mathrm{mmol} 3 \mathrm{~h} / \mathrm{L})$ & $6.75(0.78)$ & $7.33(1.58)$ \\
\hline \multicolumn{4}{|l|}{$T G$} \\
\hline $\begin{array}{r}\text { iAUC (after } \\
\text { breakfast) }\end{array}$ & $(\mathrm{mmol} 4 \mathrm{~h} / \mathrm{L})$ & $0.08(0.15)$ & $0.26(0.32)$ \\
\hline $\begin{array}{l}\text { iAUC (after } \\
\text { lunch) }\end{array}$ & $(\mathrm{mmol} 6 \mathrm{~h} / \mathrm{L})$ & $0.91(0.64)$ & $1.27(1.26)$ \\
\hline $\begin{array}{c}\text { iAUC (after } \\
\text { dinner) }\end{array}$ & $(\mathrm{mmol} 3 \mathrm{~h} / \mathrm{L})$ & $0.12(0.13)$ & $0.14(0.15)$ \\
\hline \multicolumn{4}{|l|}{ Insulin } \\
\hline $\begin{array}{r}\text { iAUC (after } \\
\text { breakfast) }\end{array}$ & $(\mu \mathrm{IU} 4 \mathrm{~h} / \mathrm{mL})$ & $55.39(39.09)$ & $56.50(44.17)$ \\
\hline $\begin{array}{l}\text { iAUC (after } \\
\text { lunch) }\end{array}$ & $(\mu \mathrm{IU} 6 \mathrm{~h} / \mathrm{mL})$ & $91.21(73.95)$ & $86.17(70.63)$ \\
\hline $\begin{array}{l}\text { iAUC (after } \\
\text { dinner) }\end{array}$ & $(\mu \mathrm{IU} 3 \mathrm{~h} / \mathrm{mL})$ & $91.10(95.36)$ & $103.72(85.75)$ \\
\hline \multicolumn{4}{|l|}{ Total GIP } \\
\hline $\begin{array}{r}\text { iAUC (after } \\
\text { breakfast) }\end{array}$ & $(\mathrm{pg} 4 \mathrm{~h} / \mathrm{mL})$ & $283.36(122.33)$ & $433.44(206.73)^{*}$ \\
\hline $\begin{array}{l}\text { iAUC (after } \\
\text { lunch) }\end{array}$ & $(\mathrm{pg} 6 \mathrm{~h} / \mathrm{mL})$ & $890.93(254.31)$ & $1287.68(662.11) \dagger$ \\
\hline $\begin{array}{c}\text { iAUC (after } \\
\text { dinner) }\end{array}$ & (pg $3 \mathrm{~h} / \mathrm{mL})$ & $274.28(151.01)$ & $662.11(149.84) \dagger$ \\
\hline
\end{tabular}

Data are expressed as means (SD); $n=9$ in each group and were analyzed by using the Wilcoxon signed-rank test

$G I P$ glucose-dependent insulinotropic polypeptide, $T G$ triglycerides

Values significantly ( $* P<0.05, \dagger P<0.01$ ) different from those of the traditional Japanese test diet are indicated

significant (Fig. 3f, $P<0.05$ ) interaction between time and diet, even though the blood active ghrelin concentration did not differ between the test diets. There was no significant correlation between the postprandial GIP and active ghrelin responses.

\section{Association between postprandial REE and postprandial blood variables}

Correlation analysis revealed that the iAUCs for postprandial REE after breakfast and lunch were positively associated (breakfast: $r_{\mathrm{s}}=0.64, P<0.01$; lunch: $r_{\mathrm{s}}=0.56$, $P<0.05)$ with the iAUC for postprandial active ghrelin (Table 4; Fig. 4a, b). The postprandial active ghrelin and REE responses were positively correlated with both the traditional (breakfast: $r_{\mathrm{s}}=0.78, P<0.05$; lunch: $r_{\mathrm{s}}=0.20, P>0.05$ ) and the modern (breakfast: $r_{\mathrm{s}}=0.67, P=0.06$; lunch:

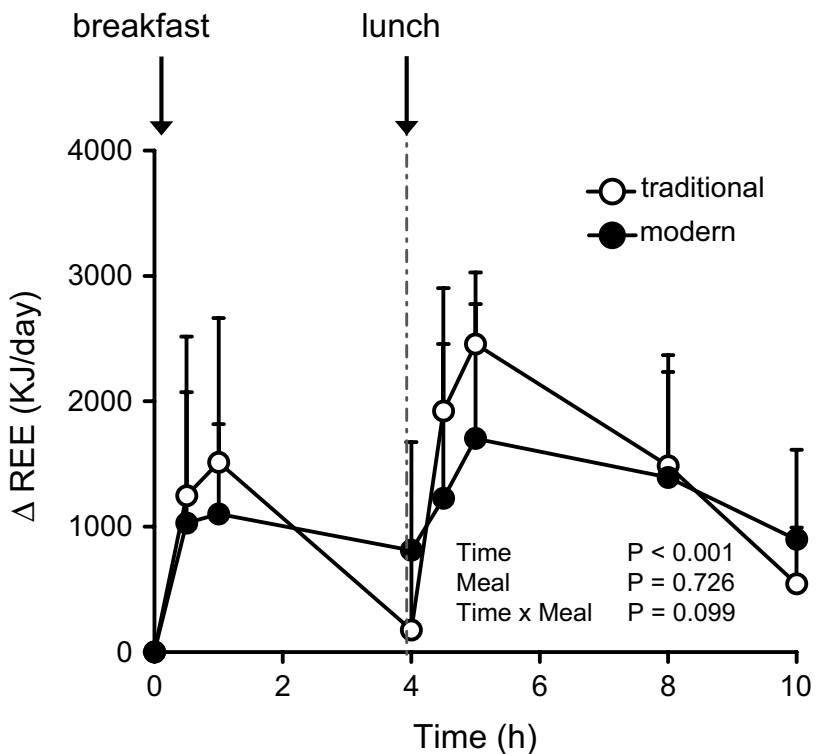

Fig. 2 Postprandial incremental resting energy expenditure ( $\triangle \mathrm{REE})$ after the consumption of the traditional Japanese test diet (open circles) or modern Japanese test diet (closed circles) in overnight-fasted healthy Japanese men. Baseline values were obtained immediately before the ingestion of the breakfast meal. Data are expressed as mean $\pm \mathrm{SD}$ ( $n=9$ in each group) and were analyzed by means of 2-way repeated-measures ANOVA

Table 2 Postprandial incremental REE (iAUCs) after the test diets

\begin{tabular}{|c|c|c|c|}
\hline & Traditional & Modern & $P$ \\
\hline After breakfast $(0-4 \mathrm{~h})(\mathrm{kJ})$ & $574.6(513.7)$ & $619.5(454.7)$ & 0.95 \\
\hline $\begin{array}{l}\text { After lunch }(4-10 \mathrm{~h})(\mathrm{kJ}) \text { : } \\
\text { the baseline levels were } \\
\text { used at } 4 \mathrm{~h}\end{array}$ & $2211.7(632.7)$ & $791.4(637.3)$ & $<0.05$ \\
\hline $\begin{array}{l}\text { After lunch }(4-10 \mathrm{~h})(\mathrm{kJ}) \text { : } \\
\text { the baseline levels were } \\
\text { used at } 0 \mathrm{~h}\end{array}$ & $2134.2(797.8)$ & $2061.8(1096.1)$ & 0.95 \\
\hline
\end{tabular}

Data are expressed as means (SD); $n=9$ in each group and were analyzed by using the Wilcoxon signed-rank test

$i A U C$ incremental area under the curve for test diet ingestion

$\left.r_{\mathrm{s}}=0.44, P>0.05\right)$ diets. When the values immediately before breakfast (at $0 \mathrm{~h}$ ) were used as the baseline levels, the iAUC of $\triangle$ REE after lunch was not positively correlated with the iAUC of active ghrelin after either the modern $\left(r_{\mathrm{s}}=0.28\right.$, $P>0.05)$ or the traditional diet $\left(r_{\mathrm{s}}=0.62, P>0.05\right)$.

The iAUC for postprandial REE after both lunches was negatively correlated $\left(r_{\mathrm{s}}=-0.69, P<0.01\right)$ with the iAUC for the postprandial GIP response (Fig. 4c), when the values immediately before lunch (at $4 \mathrm{~h}$ ) were used as the baseline levels (Table 4). When the values immediately before breakfast (at $0 \mathrm{~h}$ ) were used as the baseline levels, the iAUC of $\triangle$ REE after lunch was negatively correlated with the iAUC of GIP after the modern Japanese $\operatorname{diet}\left(r_{\mathrm{s}}=-0.83, P<0.05\right)$ 
Fig. 3 Blood glucose (a), insulin (b), triglycerides (TG; c), total glucose-dependent insulinotropic polypeptide (GIP; d), non-esterified fatty acids (NEFA; e), active ghrelin (f), cholecystokinin (CCK; g), and active glucagon-like peptide-1 (active GLP-1; h) concentrations until $10 \mathrm{~h}$ after the consumption of the traditional Japanese test diet (open circles) or modern Japanese test diet (closed circles) in overnight-fasted healthy Japanese men. Data are expressed as mean $\pm \mathrm{SD}(n=9$ in each group) and were analyzed by means of 2-way repeated-measures ANOVA

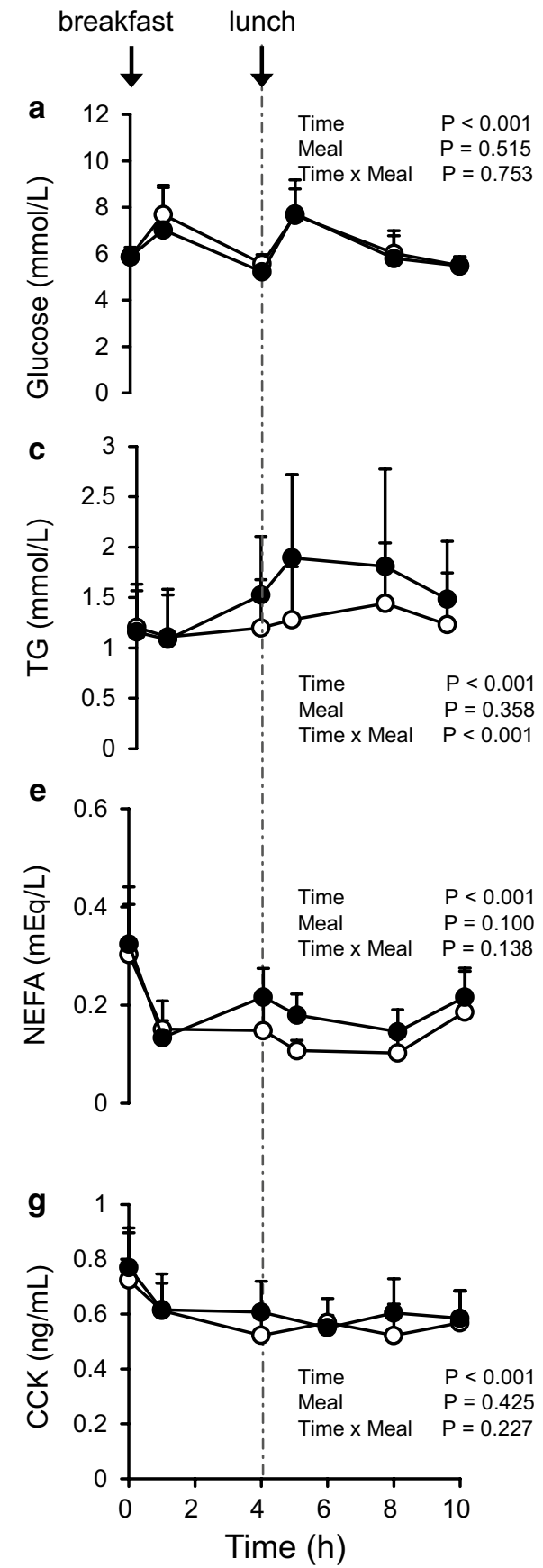

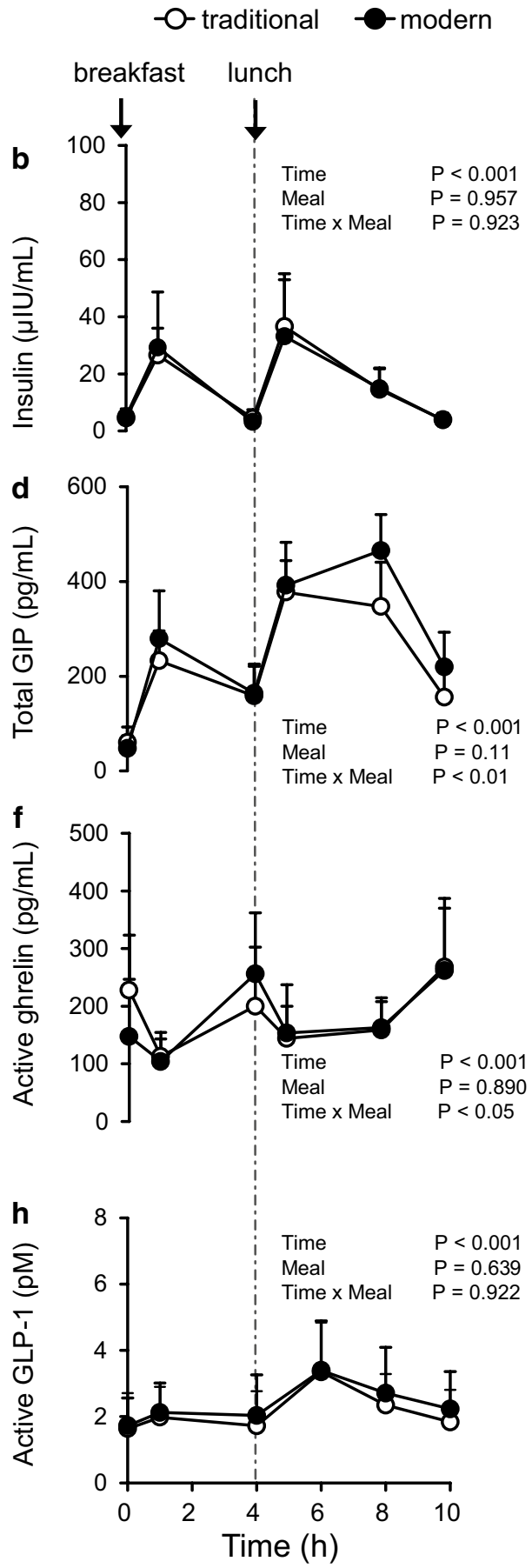

but not after the traditional diet $\left(r_{\mathrm{s}}=-0.15, P>0.05\right)$ (Fig. 4d). There was no significant correlation between postprandial TG and REE responses (Table 4).

\section{Discussion}

This study yielded two key findings. First, the study demonstrated that the nutritional composition of our modern
Japanese test diet increased postprandial GIP, TG, and active ghrelin responses compared with those of the traditional diet in healthy Japanese male adults. Second, we showed that the modern Japanese meals tended to induce less postprandial energy expenditure than did the traditional meals, especially after lunch, and were associated with increased postprandial GIP release.

Postprandial GIP release is stimulated by macronutrients, especially dietary fat $[27,30-32]$. The greater 
Table 3 Postprandial incremental areas under the curve (iAUCs) of total GIP and active ghrelin

\begin{tabular}{|c|c|c|c|}
\hline & & Traditional & Modern \\
\hline \multicolumn{4}{|l|}{ Total GIP } \\
\hline $\begin{array}{r}\text { iAUC (after } \\
\text { breakfast) }\end{array}$ & (ng $4 \mathrm{~h} / \mathrm{mL}$ ) & $0.49(0.14)$ & $0.64(0.18)$ \\
\hline $\begin{array}{l}\text { iAUC (after } \\
\text { lunch) }\end{array}$ & $(\mathrm{ng} 6 \mathrm{~h} / \mathrm{mL})$ & $0.91(0.22)$ & $1.27(0.37)^{*}$ \\
\hline $\begin{array}{l}\text { iAUC (after } \\
\text { lunch): baseline } \\
0 \mathrm{~h}\end{array}$ & $(\mathrm{ng} 6 \mathrm{~h} / \mathrm{mL})$ & $1.50(0.31)$ & $1.96(0.24)^{*}$ \\
\hline \multicolumn{4}{|l|}{ Active ghrelin } \\
\hline $\begin{array}{r}\text { iAUC (after } \\
\text { breakfast) }\end{array}$ & $(\mathrm{ng} 4 \mathrm{~h} / \mathrm{mL})$ & $39.34(82.30)$ & $175.66(128.94)^{*}$ \\
\hline $\begin{array}{l}\text { iAUC (after } \\
\text { lunch) }\end{array}$ & $(\mathrm{ng} 6 \mathrm{~h} / \mathrm{mL})$ & $116.72(200.85)$ & $25.70(50.75)$ \\
\hline $\begin{array}{l}\text { iAUC (after } \\
\text { lunch): baseline } \\
0 \mathrm{~h}\end{array}$ & $(\mathrm{ng} 6 \mathrm{~h} / \mathrm{mL})$ & 77.10 (94.96) & $343.06(236.90) *$ \\
\hline
\end{tabular}

Data are expressed as means (SD); $n=9$ in each group and were analyzed by using the Wilcoxon signed-rank test

$G I P$ glucose-dependent insulinotropic polypeptide

Values significantly $(* P<0.05)$ different from those of the traditional Japanese test diet are indicated

increase in postprandial GIP after the modern Japanese test diet seems to be due to its higher fat content compared with that of the traditional diet. In addition, the dietary fatty acid composition may have contributed to the increased GIP response after the modern meals. In the current study, the fatty acid composition (saturated/monounsaturated/polyunsaturated) was 5.9:6.7:9.1 g (27\%:31\%:42\%) for the traditional and 19.9:19.7:10.4 g (40\%:39\%:21\%) for the modern Japanese test diets. Monounsaturated fatty acids induce a stronger postprandial GIP response than do saturated fatty acids [30]. In addition, fish oil, which is rich in polyunsaturated fatty acids, suppresses the postprandial GIP response more effectively than do cocoa butter and olive oil [31]. Accordingly, the decreased polyunsaturated fatty acid content or the increased proportion of monounsaturated fatty acids (or both) may have contributed to the increase in the postprandial GIP response due to the modern Japanese test diet.

Like dietary fats, dietary protein increases postprandial GIP blood levels. Whey protein has been shown to stimulate postprandial GIP release into the blood [33]. Although the protein contents of the test diets were similar, the source of the protein differed between them: the traditional Japanese diet contained soy and fish, whereas the modern Japanese diet contained whey and meat as the main protein sources. The differences in the sources of dietary protein, which differed in amino acid composition, may have affected the postprandial GIP response. Additional studies are needed to clarify whether and how dietary protein differentially affects the postprandial GIP response in humans.

Regarding our second key finding, the results from our indirect calorimetry are consistent with the findings of Nagai et al. [34] and Maffeis et al. [35, 36], which showed that low-fat meals (energy \%, 21, 20, and 27, respectively) induced greater thermogenesis postprandially than did extremely high-fat meals (energy \%, 70, 48, and 52, respectively). Furthermore, our results parallel those from previous studies [34-36], even though the difference in the total fat content between the two test diets (energy \%, 14.8 and 27.5) was relatively low in our study.

The postprandial energy expenditure due to dietary protein is $20-35 \%$ of the energy consumption [37]. Several studies have suggested that high-protein diets lead to greater energy expenditure than do low-protein diets [38]. In the present study, the modern Japanese diet (13.1\% protein) tended to induce less energy expenditure than did the traditional diet (14.4\% protein), especially after lunch, even though the protein content of the diets was similar. The different sources of dietary protein (soy compared with milk) might be responsible for the difference between the postprandial energy expenditures of the test diets. Additional studies are needed to clarify whether and how dietary protein differentially affects postprandial thermogenesis in humans.

Accumulated evidence suggests that GIP, through its specific receptor, plays an important role in the onset of obesity by promoting energy storage in adipose tissues [18-26]. Several genome-wide association studies have identified single-nucleotide polymorphisms in the GIP receptor (GIPR) gene that are strongly associated with body mass index in humans [39-42]. Moreover, another recent study showed that the GIP/GIPR gene polymorphisms were strongly associated with visceral fat accumulation in the Japanese population [43]. In addition, increasing the blood concentration of GIP through its intravascular infusion decreased REE in healthy humans [21]. We previously showed that postprandial REE is negatively correlated with the postprandial GIP response and that a test diet that stimulated decreased postprandial GIP release was more thermogenic than was the control diet in healthy humans [44].

Like those involving human subjects, animal studies support the claim that decreased GIP signaling increases energy expenditure and suppresses body fat accumulation. Our previous study demonstrated that increasing blood GIP levels through chronic administration of GIP reduced fat utilization in high-fat fed mice [45]. The genetic ablation of either the GIPR [22] or of GIP-secreting enteroendocrine cells [20] prevented the onset of obesity and increased fat oxidation under high-fat diets through an unknown mechanism. The GIP receptor is expressed in pancreas, stomach, small intestine, heart, adrenal cortex, brain, lung, bone, 
Table 4 Spearman's rank correlation coefficients $\left(r_{\mathrm{s}}\right)$ between postprandial iAUCs of REE and blood variable response

\begin{tabular}{|c|c|c|}
\hline & \multicolumn{2}{|c|}{ Postprandial $\triangle$ REE (iAUC) } \\
\hline & After breakfast $0-4 \mathrm{~h}$ & After lunch $4-10 \mathrm{~h}$ \\
\hline \multicolumn{3}{|l|}{ Total GIP } \\
\hline After breakfast $0-4 \mathrm{~h}$ & -0.07 & - \\
\hline After lunch $4-10 \mathrm{~h}$ : the levels at $4 \mathrm{~h}$ were used as baseline & - & $-0.69^{\dagger}$ \\
\hline $\begin{array}{l}\text { After lunch } 4-10 \mathrm{~h} \text { : the levels at } 0 \mathrm{~h} \text { were used as baseline } \\
\text { Insulin }\end{array}$ & - & -0.23 \\
\hline After breakfast $0-4 \mathrm{~h}$ & -0.23 & - \\
\hline After lunch $4-10 \mathrm{~h}$ : the levels at $4 \mathrm{~h}$ were used as baseline & - & 0.05 \\
\hline $\begin{array}{l}\text { After lunch } 4-10 \mathrm{~h} \text { : the levels at } 0 \mathrm{~h} \text { were used as baseline } \\
\text { Active GLP-1 }\end{array}$ & - & -0.34 \\
\hline After breakfast $0-4 \mathrm{~h}$ & 0.27 & - \\
\hline After lunch $4-10 \mathrm{~h}$ : the levels at $4 \mathrm{~h}$ were used as baseline & - & -0.24 \\
\hline $\begin{array}{l}\text { After lunch } 4-10 \mathrm{~h} \text { : the levels at } 0 \mathrm{~h} \text { were used as baseline } \\
\text { Active ghrelin }\end{array}$ & - & 0.06 \\
\hline After breakfast $0-4 \mathrm{~h}$ & $0.64^{\dagger}$ & - \\
\hline After lunch $4-10 \mathrm{~h}$ : the levels at $4 \mathrm{~h}$ were used as baseline & - & $0.56^{*}$ \\
\hline $\begin{array}{l}\text { After lunch } 4-10 \mathrm{~h} \text { : the levels at } 0 \mathrm{~h} \text { were used as baseline } \\
C C K\end{array}$ & - & 0.31 \\
\hline After breakfast $0-4 \mathrm{~h}$ & 0.10 & - \\
\hline After lunch $4-10 \mathrm{~h}$ : the levels at $4 \mathrm{~h}$ were used as baseline & - & 0.32 \\
\hline $\begin{array}{l}\text { After lunch } 4-10 \mathrm{~h} \text { : the levels at } 0 \mathrm{~h} \text { were used as baseline } \\
T G\end{array}$ & - & -0.01 \\
\hline After breakfast $0-4 \mathrm{~h}$ & 0.03 & - \\
\hline After lunch $4-10 \mathrm{~h}$ : the levels at $4 \mathrm{~h}$ were used as baseline & - & -0.21 \\
\hline After lunch $4-10 \mathrm{~h}$ : the levels at $0 \mathrm{~h}$ were used as baseline & - & 0.08 \\
\hline
\end{tabular}

$C C K$ cholecystokinin, GIP glucose-dependent insulinotropic polypeptide, GLP-1 glucagon-like peptide-1, $T G$ triglycerides, iAUC incremental area under the curve after the ingestion of test meals

Spearman's rank correlation coefficients were obtained when comparing paired samples whose data were not normally distributed $(* P<0.05 ; \dagger P<0.01)$ between two parameters vascular endothelium, and adipose tissue [46]. Although skeletal muscle and liver are the predominant sites of body fat oxidation, they do not express the GIP receptor. As a possible mechanism for linking GIP and energy catabolism, Naitoh et al. [47] showed that chronic inhibition of GIP signaling increased plasma adiponectin levels, resulting in increased fat oxidation in the skeletal muscle tissues of mice fed a high-fat diet. Decreased GIP secretion may increase energy expenditure through the stimulation of adiponectin signaling. However, whether this mechanism holds true during the postprandial state of humans is unclear, because the blood adiponectin level did not change after meal ingestion by human subjects [48]. Additional research is needed to clarify the role of adiponectin in linking postprandial GIP and energy expenditure in humans.

The GIP receptor is expressed in pituitary, adrenal cortex [46], and brown adipose tissue [49], all of which play important roles in energy homeostasis, including diet-induced thermogenesis. Therefore, as another possible mechanism linking postprandial GIP and energy expenditure, the increased GIP signaling after the modern Japanese diet may somehow modulate these tissues and thus downregulate energy expenditure. However, the physiologic function of GIP in pituitary, adrenal cortex, and brown adipose tissue in relation to postprandial energy expenditure is unclear and warrants investigation.

Blood concentrations of active ghrelin were positively correlated with the postprandial REE after breakfast and lunch, suggesting that, like GIP, postprandial ghrelin is a robust indicator of postprandial thermogenesis and the magnitude of the increase in active ghrelin seems to dictate the increase in postprandial energy expenditure. However, the postprandial increase in ghrelin was greater after the modern Japanese meal than the traditional meal-a finding that is incompatible with the result that the postprandial energy expenditure was lower after the modern Japanese diet than the traditional diet. Accordingly, the increase in the active ghrelin response does not seem to be predominantly responsible for the increased postprandial thermogenesis after the modern Japanese meals. Although 
Fig. 4 Correlation between the postprandial incremental area under the curve (iAUC) for $\triangle \mathrm{REE}$ and postprandial blood levels of gastrointestinal hormones. a Correlation between iAUC- $\triangle$ REE after breakfast and iAUC for active ghrelin. b Correlation between iAUC$\triangle \mathrm{REE}$ after lunch and iAUC for active ghrelin. c, $\mathbf{d}$ Correlation of iAUC- $\triangle$ REE after lunch with the iAUC for total GIP $\mathbf{c}$ when the values obtained immediately before ingestion of lunch (at $4 \mathrm{~h}$ ) were used as baseline data and $\mathbf{d}$ when the values obtained immediately before breakfast (at $0 \mathrm{~h}$ ) were used as the baseline levels. Spearman's rank correlation coefficients were obtained when comparing paired samples whose data were not normally distributed. Correlations were considered significant when the error probability was $<0.05$
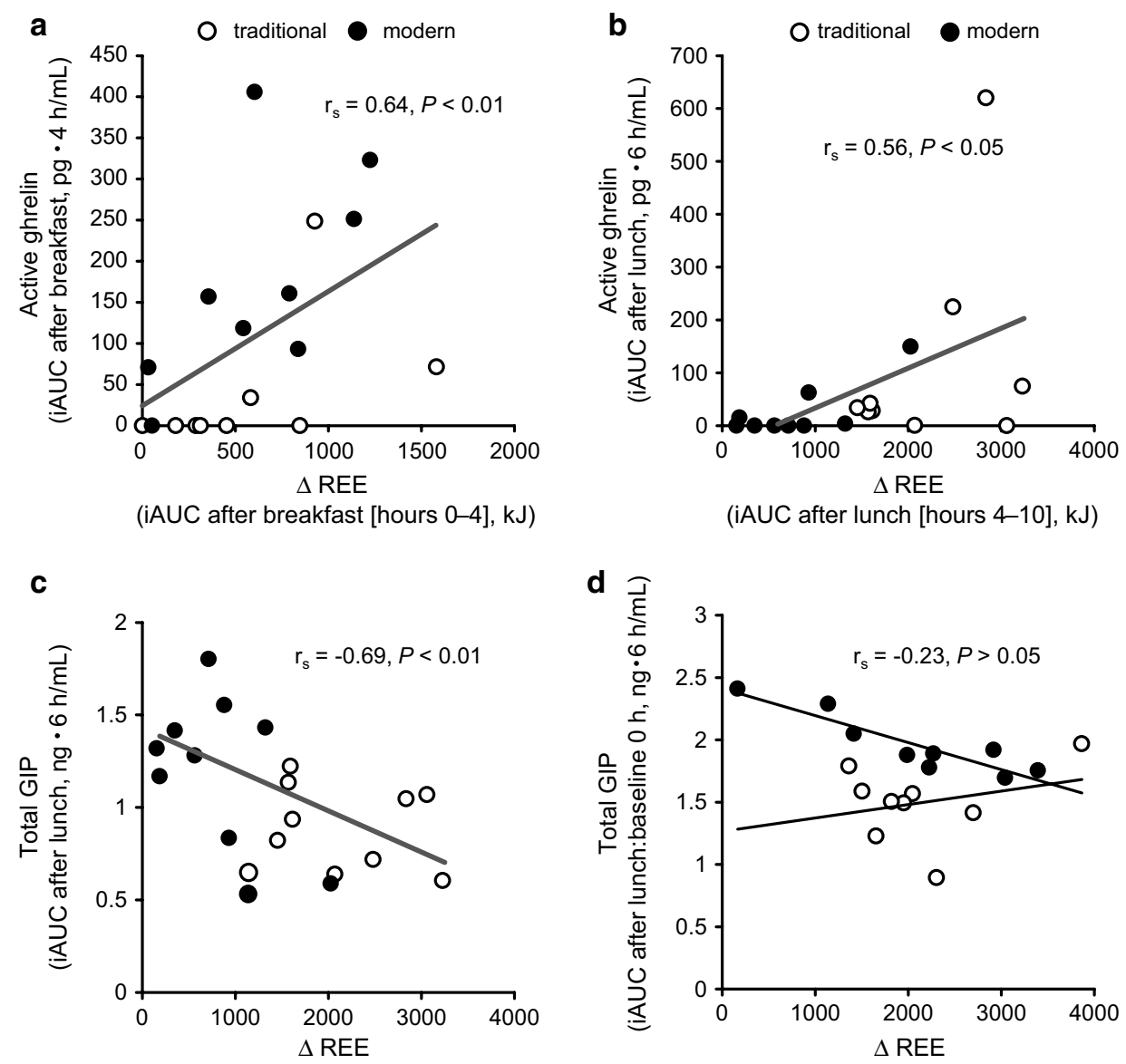

(iAUC after lunch [hours 4-10], kJ)

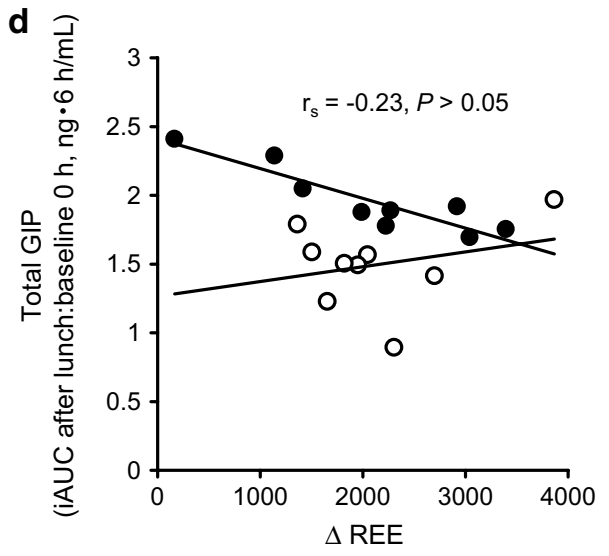

(iAUC after lunch [hours 4-10]: baseline $0 \mathrm{~h}, \mathrm{~kJ}$ ) increasing levels of active ghrelin during fasting has been shown to stimulate the appetite [13-16], the effect of ghrelin on energy expenditure has not been reported. Ghrelin increases hunger, food intake, and fat deposition by binding to its specific receptor in the ventromedial hypothalamus $[50,51]$. In addition, electrical stimulation of the ventromedial hypothalamus of rats increased energy expenditure [52] and thermogenesis in brown adipose tissue [53]. Accordingly, ghrelin may increase energy expenditure through a hypothalamic mechanism. In one study [54], higher fasting blood ghrelin levels were associated with lower DIT, suggesting that ghrelin plays a significant role in regulating postprandial energy expenditure. In contrast, the role of the postprandial blood ghrelin response in regulating DIT remains to be clarified. In this regard, a high-protein diet was reported to increase postprandial thermogenesis but to blunt the postprandial blood ghrelin response [55]. However, blood ghrelin levels did not differ between the highprotein and the protein-sufficient diets in another experiment [56]. The relationship between the postprandial blood ghrelin response and DIT is therefore unresolved still.

The postprandial blood GIP response was negatively correlated with postprandial REE after the modern
Japanese lunch but not after the traditional lunch (Fig. 4d). One possible explanation for this inverse correlation only after the modern Japanese lunch may be due to the concurrent increases in blood GIP and TG concentrations during and after the meal. Studies have shown that GIP increases the synthesis and secretion of lipoprotein lipase (LPL) in adipocytes [23, 57] and promotes the activity of LPL in fat tissue [58]. When the drop in LPL activity due to decreased GIP signaling in adipose tissue coincides with increased blood TG levels, the amount of fat released into the circulation may increase. In fact, ingestion of the modern Japanese diet (27.5\% fat content) increased the blood TG response more than twice that induced by the traditional diet (14.8\% fat content) (Fig. 1c), and the postprandial GIP response after the modern diet was almost double that after the traditional diet (Fig. 1d), supporting the hypothesis that concurrent increases in blood GIP and TG increase the amount of fat distributed to the circulation. When the postprandial GIP response is decreased in the context of increased blood TG, more fat may be distributed to energy-utilizing tissues such as skeletal muscle and liver, both of which lack the GIP receptor, to a greater extent than to energy-storing adipose tissues, thus increasing fat oxidation. However, 
the precise link between postprandial GIP signaling and whole-body energy utilization remains unclear and merits additional research.

Correlation analysis revealed that the iAUCs for the postprandial blood responses of CCK and active GLP-1 were not associated with postprandial REE in the current study, in contrast with the well-known correlation between GLP-1 and postprandial energy expenditure in other studies $[59,60]$. The reason for these differing results is unclear but may reflect differences between the study protocols, including the dose of GLP-1. In addition, the postprandial increase in the blood level of active GLP-1 that we obtained in the current study was smaller than those in other studies $[59,60]$. Additional work is needed to clarify the role of GLP-1 in postprandial energy expenditure.

According to the National Health and Nutrition Survey in Japan, the composition of the Japanese diet has changed markedly since 1960 . However, the effect of dietary composition on energy homeostasis has been little investigated. The model composition of the average Japanese diet in 1975 was less obesity-inducing than was that in 2005 [61]. In the current study, the postprandial thermogenesis after the modern Japanese lunch was $1420 \mathrm{~kJ}$ less than that of the traditional Japanese lunch on average, which corresponds to $1.1 \mathrm{~kg}$ body fat per month. These results suggest that the nutritional change that accompanies the modernization of the Japanese dietary composition may increase body fat accumulation. The results of our current study also suggest that the postprandial GIP and active ghrelin responses are reliable predictors of postprandial REE and might be used as markers for designing obesity-preventive meals. In addition, our previous studies have consistently demonstrated that decreasing the diet-induced GIP response leads to increased energy expenditure and prevents high-fat dietinduced obesity in mice [44, 62].

A potential weakness of the present study is that our study population was small. Using a larger study population would be valuable for clarifying whether modern Japanese meals are less thermogenic than are traditional Japanese meals. Another limitation is that we did not address the mechanisms underlying the negative correlation between the postprandial GIP response and postprandial REE. Although GIP is well known as an incretin hormone that potentiates glucose-induced secretion of insulin from pancreatic $\beta$ cells, blood insulin levels did not differ postprandially between the test diets. Accordingly, the extrapancreatic action of GIP-rather than its insulinotropic action-seems to facilitate the downregulation of postprandial energy expenditure. Additional studies are needed to clarify how blood GIP lowers postprandial thermogenesis. Another limitation of the present study is that the mechanisms underlying the positive correlation between the postprandial active ghrelin response and postprandial REE remain elusive. The contribution of the increase in ghrelin content to the decreased postprandial energy expenditure after the modern diet warrants further investigation.

In conclusion, the current study demonstrates that the modern Japanese test diet induced greater postprandial blood GIP and ghrelin levels than did traditional Japanese meals, and these hormonal responses were associated with postprandial thermogenesis in healthy Japanese men. We believe that not only the increased calorie intake but also the changes in the macronutrient composition that accompany the modernization of Japanese dietary patterns cause body weight and fat gain by altering the release of metabolism-regulating hormones to become more anabolic. The results of our study also indicate that the meal-induced release in the intestinal anabolic hormone GIP and the gastric hunger hormone ghrelin may be markers of postprandial thermogenesis and therefore may facilitate the design of obesity-preventative meals. The pairing of an increased postprandial ghrelin response with reduced the postprandial energy expenditure after the modern Japanese diet was inconsistent with the positive correlation between postprandial ghrelin response and energy expenditure; however, these data are inconclusive and merit further study. Our on-going studies seek to clarify whether and how the daily consumption of "low GIP meals" decreases body weight and fat mass in obese and overweight subjects. Additional detailed studies on the relationship among diet-induced GIP and ghrelin responses and postprandial energy homeostasis are warranted.

Acknowledgments The present study was supported financially by Kao Corporation.

\section{Compliance with ethical standards}

\section{Conflict of interest None.}

Open Access This article is distributed under the terms of the Creative Commons Attribution 4.0 International License (http://creativecommons.org/licenses/by/4.0/), which permits unrestricted use, distribution, and reproduction in any medium, provided you give appropriate credit to the original author(s) and the source, provide a link to the Creative Commons license, and indicate if changes were made.

\section{References}

1. National Institutes of Health (1998) Clinical guidelines on the identification, evaluation, and treatment of overweight and obesity in adults - the evidence report. Obes Res 6:51S-209S

2. OECD Health Data (2011) National sources for non-OECD countries. http://www.oecd.org/els/health-systems/49105858.pdf

3. Tada N, Maruyama C, Koba S, Tanaka H, Birou S, Teramoto T, Sasaki J (2011) Japanese dietary lifestyle and cardiovascular disease. J Atheroscler Thromb 18:723-734 
4. Shimazu T, Kuriyama S, Hozawa A, Ohmori K, Sato Y, Nakaya N, Nishino Y, Tsubono Y, Tsuji I (2007) Dietary patterns and cardiovascular disease mortality in Japan: a prospective cohort study. Int J Epidemiol 36:600-609

5. Sadakane A, Tsutsumi A, Gotoh T, Ishikawa S, Ojima T, Kario K, Nakamura Y, Kayaba K (2008) Dietary patterns and levels of blood pressure and serum lipids in a Japanese population. J Epidemiol 18:58-67

6. Iso H, Date C, Wakai K, Fukui M, Tamakoshi A, JACC Study Group (2006) The relationship between green tea and total caffeine intake and risk for self-reported type 2 diabetes among Japanese adults. Ann Intern Med 144:554-562

7. Hirayama T (1982) Relationship of soybean paste soup intake to gastric cancer risk. Nutr Cancer 3:223-233

8. Willett WC (1994) Diet and health: what should we eat? Science 264:532-537

9. Ministry of Agriculture, Forestry and Fisheries of Japan: Abstract of statistics on agriculture forestry and fisheries in Japan. (in Japanese) http://www.mwff.go.jp/j/tokei/index.html

10. The National Health and Nutrition Survey in Japan 2008 report. (in Japanese) http://www.mhlw.go.jp/bunya/kenkou/eiyou/dl/ h20-houkoku-kekka.pdf

11. Adrian TE, Ferri GL, Bacarese-Hamilton AJ, Fuessl HS, Polak JM, Bloom SR (1985) Human distribution and release of a putative new gut hormone, peptide YY. Gastroenterology 89:1070-1077

12. Batterham RL, Cohen MA, Ellis SM, Le Roux CW, Withers DJ, Frost GS, Ghatei MA, Bloom SR (2003) Inhibition of food intake in obese subjects by peptide YY3-36. N Engl J Med 349:941-948

13. Ariyasu H, Takaya K, Tagami T, Ogawa Y, Hosoda K, Akamizu T, Suda M, Koh T, Natsui K, Toyooka S, Shirakami G, Usui T, Shimatsu A, Doi K, Hosoda H, Kojima M, Kangawa K, Nakao $\mathrm{K}$ (2001) Stomach is a major source of circulating ghrelin, and feeding state determines plasma ghrelin-like immunoreactivity levels in humans. J Clin Endocrinol Metab 86:4753-4758

14. Kojima M, Hosoda H, Date Y, Nakazato M, Matsuo H, Kangawa $\mathrm{K}$ (1999) Ghrelin is a growth-hormone-releasing acylated peptide from stomach. Nature 402:656-660

15. Cummings DE, Purnell JQ, Frayo RS, Schmidova K, Wisse BE, Weigle DS (2001) A preprandial rise in plasma ghrelin levels suggests a role in meal initiation in humans. Diabetes 50:1714-1719

16. Cummings DE, Frayo RS, Marmonier C, Aubert R, Chapelot D (2004) Plasma ghrelin levels and hunger scores in humans initiating meals voluntarily without time- and food-related cues. Am J Physiol Endocrinol Metab 287:E297-E304

17. Baggio LL, Drucker DJ (2007) Biology of incretins: GLP1 and GIP. Gastroenterology 132:2131-2157

18. Irwin N, Flatt PR (2009) Therapeutic potential for GIP receptor agonists and antagonists. Best Pract Res Clin Endocrinol Metab 23:499-512

19. Song DH, Wolfe MM (2007) Glucose-dependent insulinotropic polypeptide and its role in obesity. Curr Opin Endocrinol Diabetes Obes 14:46-51

20. Althage MC, Ford EL, Wang S, Tso P, Polonsky KS, Wice BM (2008) Targeted ablation of glucose-dependent insulinotropic polypeptide-producing cells in transgenic mice reduces obesity and insulin resistance induced by a high fat diet. J Biol Chem 283:18365-18376

21. Daousi C, Wilding JP, Aditya S, Durham BH, Cleator J, Pinkney JH, Ranganath LR (2009) Effects of peripheral administration of synthetic human glucose-dependent insulinotropic peptide (GIP) on energy expenditure and subjective appetite sensations in healthy normal weight subjects and obese patients with type 2 diabetes. Clin Endocrinol 71:195-201
22. Miyawaki K, Yamada Y, Ban N, Ihara Y, Tsukiyama K, Zhou H, Fujimoto S, Oku A, Tsuda K, Toyokuni S, Hiai H, Mizunoya W, Fushiki T, Holst JJ, Makino M, Tashita A, Kobara Y, Tsubamoto Y, Jinnouchi T, Jomori T, Seino Y (2002) Inhibition of gastric inhibitory polypeptide signaling prevents obesity. Nat Med 8:738-742

23. Eckel RH, Fujimoto WY, Brunzell JD (1979) Gastric inhibitory polypeptide enhanced lipoprotein lipase activity in cultured preadipocytes. Diabetes 28:1141-1142

24. Beck B, Max JP (1983) Gastric inhibitory polypeptide enhancement of the insulin effect on fatty acid incorporation into adipose tissue in the rat. Regul Pept 7:3-8

25. Oben J, Morgan L, Fletcher J, Marks V (1991) Effect of the entero-pancreatic hormones, gastric inhibitory polypeptide and glucagon-like polypeptide-1(7-36) amide, on fatty acid synthesis in explants of rat adipose tissue. J Endocrinol 130:267-272

26. Drucker DJ (2006) The biology of incretin hormones. Cell Metab 3:153-165

27. Elliott RM, Morgan LM, Tredger JA, Deacon S, Wright J, Marks V (1993) Glucagon-like peptide-1(7-36) amide and glucosedependent insulinotropic polypeptide secretion in response to nutrient ingestion in man: acute post-prandial and 24-h secretion patterns. J Endocrinol 138:159-166

28. Weir J (1949) New methods for calculating metabolic rate with special reference to protein metabolism. J Physiol 109:1-9

29. Wolever TM (2004) Effect of blood sampling schedule and method of calculating the area under the curve on validity and precision of glycaemic index values. Br J Nutr 91:295-301

30. Thomsen C, Rasmussen O, Lousen T, Holst JJ, Fenselau S, Schrezenmeir J, Hermansen K (1999) Differential effects of saturated and monounsaturated fatty acids on postprandial lipemia and incretin responses in healthy subjects. Am J Clin Nutr 69:1135-1143

31. Lardinois CK, Starich GH, Mazzaferri EL (1988) The postprandial response of gastric inhibitory polypeptide to various dietary fats in man. J Am Coll Nutr 7:241-247

32. Vilsbøll T, Krarup T, Sonne J, Madsbad S, Vølund A, Juul AG, Holst JJ (2003) Incretin secretion in relation to meal size and body weight in healthy subjects and people with type 1 and type 2 diabetes mellitus. J Clin Endocrinol Metab 88:2706-2713

33. Frid AH, Nilsson M, Holst JJ, Björck IM (2005) Effect of whey on blood glucose and insulin responses to composite breakfast and lunch meals in type 2 diabetic subjects. Am J Clin Nutr 82:69-75

34. Nagai N, Sakane N, Moritani T (2005) Metabolic responses to high-fat or low-fat meals and association with sympathetic nervous system activity in healthy young men. J Nutr Sci Vitaminol $51: 355-360$

35. Maffeis C, Schutz Y, Grezzani A, Provera S, Piacentini G, Tatò L (2001) Meal-induced thermogenesis and obesity: is fat meal a risk factor for fat gain in children? J Clin Endocrinol Metab $86: 214-219$

36. Maffeis C, Surano MG, Cordioli S, Gasperotti S, Corradi M, Pinelli L (2010) A high-fat vs. a moderate-fat meal in obese boys: nutrient balance, appetite, and gastrointestinal hormone changes. Obesity 18:449-455

37. Westerterp KR, Wilson SA, Rolland V (1999) Diet-induced thermogenesis measured over $24 \mathrm{~h}$ in a respiration chamber: effect of diet composition. Int J Obes Relat Metab Disord 23:287-292

38. Halton TL, Hu FB (2004) The effects of high protein diets on thermogenesis, satiety, and weight loss: a critical review. J Am Coll Nutr 23:373-385

39. Saxena R, Hivert MF, Langenberg $C$ et al (2010) Genetic variation in GIPR influences the glucose and insulin responses to an oral glucose challenge. Nat Genet 42:142-148 
40. Speliotes EK, Willer CJ, Berndt SI et al (2010) Association analyses of 249,796 individuals reveal 18 new loci associated with body mass index. Nat Genet 42:937-948

41. Wen W, Cho YS, Zheng W et al (2012) Meta-analysis identifies common variants associated with body mass index in east Asians. Nat Genet 44:307-311

42. Okada $\mathrm{Y}$, Kubo M, Ohmiya $\mathrm{H}$ et al (2012) Common variants at CDKAL1 and KLF9 are associated with body mass index in East Asian populations. Nat Genet 44:302-306

43. Nakayama K, Watanabe K, Boonvisut S, Makishima S, Miyashita H, Iwamoto S (2014) Common variants of GIP are associated with visceral fat accumulation in Japanese adults. Am J Physiol Gastrointest Liver Physiol 307:G1108-G1114

44. Shimotoyodome A, Suzuki J, Kameo Y, Hase T (2011) Dietary supplementation with hydroxypropyl-distarch phosphate from waxy maize starch increases resting energy expenditure by lowering the postprandial glucose-dependent insulinotropic polypeptide response in human subjects. Br J Nutr 106:96-104

45. Shimotoyodome A, Suzuki J, Fukuoka D, Tokimitsu I, Hase T (2010) RS4-type resistant starch prevents high-fat diet-induced obesity via increased hepatic fatty acid oxidation and decreased postprandial GIP in C57BL/6 J mice. Am J Physiol Endocrinol Metab 298:E652-E662

46. Usdin TB, Mezey E, Button DC, Brownstein MJ, Bonner TI (1993) Gastric inhibitory polypeptide receptor, a member of the secretin-vasoactive intestinal peptide receptor family, is widely distributed in peripheral organs and the brain. Endocrinology 133:2861-2870

47. Naitoh R, Miyawaki K, Harada N, Mizunoya W, Toyoda K, Fushiki T, Yamada Y, Seino Y, Inagaki N (2008) Inhibition of GIP signaling modulates adiponectin levels under high-fat diet in mice. Biochem Biophys Res Commun 376:21-25

48. Peake PW, Kriketos AD, Denyer GS, Campbell LV, Charlesworth JA (2003) The postprandial response of adiponectin to a high-fat meal in normal and insulin-resistant subjects. Int $\mathrm{J}$ Obes Relat Metab Disord 27:657-662

49. McIntosh CH, Widenmaier S, Kim SJ (2012) Glucose-dependent insulinotropic polypeptide signaling in pancreatic $\beta$-cells and adipocytes. J Diabetes Investig 3:96-106

50. Kamegai J, Tamura H, Shimizu T, Ishii S, Sugihara H, Wakabayashi I (2000) Central effect of ghrelin, an endogenous growth hormone secretagogue, on hypothalamic peptide gene expression. Endocrinology 141:4797-4800

51. Tschöp M, Smiley DL, Heiman ML (2000) Ghrelin induces adiposity in rodents. Nature 407:908-913

52. Ruffin M, Nicolaidis S (1999) Electrical stimulation of the ventromedial hypothalamus enhances both fat utilization and metabolic rate that precede and parallel the inhibition of feeding behavior. Brain Res 846:23-29

53. Perkins MN, Rothwell NJ, Stock MJ, Stone TW (1981) Activation of brown adipose tissue thermogenesis by the ventromedial hypothalamus. Nature 289:401-402

54. St-Pierre DH, Karelis AD, Cianflone K, Conus F, Mignault D, Rabasa-Lhoret R, St-Onge M, Tremblay-Lebeau A, Poehlman ET (2004) Relationship between ghrelin and energy expenditure in healthy young women. J Clin Endocrinol Metab 89:5993-5997

55. Marzullo P, Caumo A, Savia G, Verti B, Walker GE, Maestrini S, Tagliaferri A, Di Blasio AM, Liuzzi A (2006) Predictors of postabsorptive ghrelin secretion after intake of different macronutrients. J Clin Endocrinol Metab 91:4124-4130

56. Lejeune MP, Westerterp KR, Adam TC, Luscombe-Marsh ND, Westerterp-Plantenga MS (2006) Ghrelin and glucagon-like peptide 1 concentrations, 24-h satiety, and energy and substrate metabolism during a high-protein diet and measured in a respiration chamber. Am J Clin Nutr 83:89-94

57. Kim SJ, Nian C, McIntosh CH (2007) Activation of lipoprotein lipase by glucose-dependent insulinotropic polypeptide in adipocytes. A role for a protein kinase B, LKB1, and AMP-activated protein kinase cascade. J Biol Chem 282:8557-8567

58. Knapper JM, Puddicombe SM, Morgan LM, Fletcher JM (1995) Investigations into the actions of glucose-dependent insulinotropic polypeptide and glucagon-like peptide-1(7-36) amide on lipoprotein lipase activity in explants of rat adipose tissue. J Nutr 125:183-188

59. Flint A, Raben A, Rehfeld JF, Holst JJ, Astrup A (2000) The effect of glucagon-like peptide-1 on energy expenditure and substrate metabolism in humans. Int J Obes Relat Metab Disord 24:288-298

60. Shalev A, Holst JJ, Keller U (1997) Effects of glucagon-like peptide 1 (7-36 amide) on whole-body protein metabolism in healthy man. Eur J Clin Invest 27:10-16

61. Honma T, Kitano Y, Kijima R, Jibu Y, Kawakami Y, Tsuduki T, Nakagawa K, Miyazawa T (2013) Comparison of the health benefits of different eras of Japanese foods. Lipid and carbohydrate metabolism focused research. Nippon Shokuhin Kagaku Kogaku Kaishi 60:541-553 (in Japanese)

62. Shimotoyodome A, Osaki N, Onizawa K, Mizuno T, Suzukamo C, Okahara F, Fukuoka D, Hase T (2012) Dietary 1-monoolein decreases postprandial GIP release by reducing jejunal transport of glucose and fatty acid in rodents. Am J Physiol Gastrointest Liver Physiol 303:G298-G310 